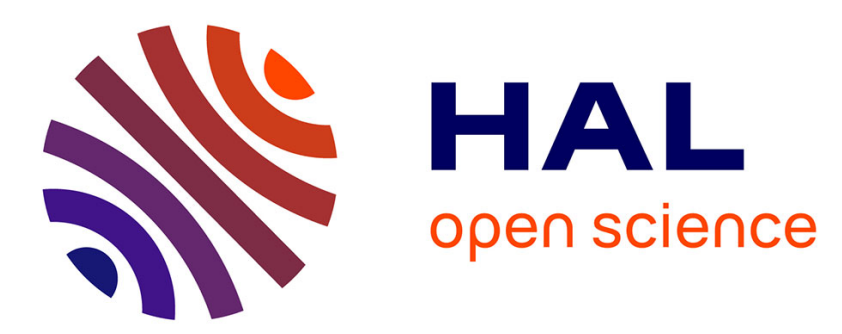

\title{
Diversity of anatomical structure of tension wood among 242 tropical tree species
}

Barbara Ghislain, Julien Engel, Bruno Clair

\section{To cite this version:}

Barbara Ghislain, Julien Engel, Bruno Clair. Diversity of anatomical structure of tension wood among 242 tropical tree species. IAWA Journal, 2019, 40 (4), pp.765-784. 10.1163/22941932-40190257 . hal03122129

\section{HAL Id: hal-03122129 \\ https://hal.inrae.fr/hal-03122129}

Submitted on 16 Sep 2021

HAL is a multi-disciplinary open access archive for the deposit and dissemination of scientific research documents, whether they are published or not. The documents may come from teaching and research institutions in France or abroad, or from public or private research centers.
L'archive ouverte pluridisciplinaire HAL, est destinée au dépôt et à la diffusion de documents scientifiques de niveau recherche, publiés ou non, émanant des établissements d'enseignement et de recherche français ou étrangers, des laboratoires publics ou privés. 


\title{
Diversity of anatomical structure of tension wood among 242 tropical tree species
}

\author{
Barbara Ghislain 1,*, Julien Engel ${ }^{1,2,3}$, and Bruno Clair ${ }^{1,4}$ \\ ${ }^{1}$ CNRS, UMR EcoFoG, AgroParisTech, Cirad, INRA, Université des Antilles, \\ Université de Guyane, Kourou, France. \\ ${ }^{2}$ AMAP, IRD, Université Montpellier, Cirad, CNRS, INRA, Montpellier, France. \\ ${ }^{3}$ International Center for Tropical Botany (ICTB), Department of Biological Sciences, \\ Florida International University, 11200 SW 8th Street, OE 243, Miami, FL 33199, U.S. A. \\ ${ }^{4}$ LMGC, Université Montpellier, CNRS, Montpellier, France. \\ *Corresponding author; e-mail: barbara.ghislain@gmail.com
}

\begin{abstract}
Angiosperm trees produce tension wood to actively control their vertical position. Tension wood has often been characterised by the presence of an unlignified inner fibre wall layer called the G-layer. Using this definition, previous reports indicate that only one-third of all tree species have tension wood with G-layers. Here we aim to (i) describe the large diversity of tension wood anatomy in tropical tree species, taking advantage of the recent understanding of tension wood anatomy and (ii) explore any link between this diversity and other ecological traits of the species. We sampled tension wood and normal wood in 432 trees from 242 species in French Guiana. The samples were observed using safranin and astra blue staining combined with optical microscopy. Species were assigned to four anatomical groups depending on the presence/absence of G-layers, and their degree of lignification. The groups were analysed for functional traits including wood density and light preferences. Eighty-six \% of the species had G-layers in their tension wood which was lignified in most species, with various patterns of lignification. Only a few species did not have G-layers. We found significantly more species with lignified G-layers among shade-tolerant and shade-demanding species as well as species with a high wood density. Our results bring up-to-date the incidence of species with/without G-layers in the tropical lowland forest where lignified G-layers are the most common anatomy of tension wood. Species without G-layers may share a common mechanism with the bark motor taking over the wood motor. We discuss the functional role of lignin in the G-layer.
\end{abstract}

Keywords: Tension wood, tropical rainforest, trees, G-layer, lignification, diversity. 


\section{INTRODUCTION}

A tropical rainforest is characterised by strong competition between species. The settlement and survival of tree species, therefore, leads to a high diversification in ecological strategies. To understand these strategies and classify tree species based on their ecological performance, ecologists have defined 'functional traits'. Trees were first mainly studied through functional traits of the leaf and seed. More recently, the focus has shifted towards stem attributes, such as the mechanical and conductive system in wood (Chave et al. 2009) and bark (Rosell \& Olson 2014), crucial for elevating and maintaining the leaves at appropriate light levels. Several functional traits have been defined covering most requirements of the plant: vessel diameter, vessel length, vessel frequency and vessel grouping describing the hydraulic efficiency (Fortunel et al. 2014), parenchyma cells, characterising the metabolic reserves of the tree (Morris \& Jansen 2016), and bark thickness in terms of a defence system (Rosell 2016). Regarding mechanical requirements, the support function of the stem is achieved by wood strength and stiffness for which wood density is a good proxy (Dlouhá et al.2018). But a strong skeleton is not sufficient to build high, slender and vertical structures such as tree stems (Moulia et al. 2006). The increasing weight of stem and crown during growth would tend to bend the stem downwards if the tree had no motor system to correct its position (Alméras \& Fournier 2009). In order to maintain a vertical position or to upright the stem after a disturbance (fall of a branch or tree fall, collapse of a shore edge, trampling of a seedling by an animal) a motor system is essential, and it is, therefore, necessary to include functional traits of the motor system in ecological studies (Fournier et al. 2013). This motor system was long thought to be achieved only by wood through the differentiation of a tissue called reaction wood (Gardiner et al. 2014). Reaction wood in most angiosperms is called tension wood as it generates strong tensile stress on the upper side of a leaning stem and acts like a guy-rope bending the stem upward. Recently, phloem has been found to provide another mechanism in some tree species (Clair et al. 2019; Lehnebach et al. 2019), replacing or acting together with tension wood (Ghislain et al. 2019, in press).

Tension wood has historically been characterised by the presence of a gelatinous layer (G-layer) (IAWA Committee 1964) replacing the $\mathrm{S}_{3}$ layer and part or the whole of the $\mathrm{S}_{2}$ layer of the wood fibres. This G-layer has highly crystalline cellulose almost aligned parallel to the cell axis and arranged in a trellis-like network filled by a gellike mesoporous matrix (Clair et al.2008) consisting of polysaccharides and proteins (Guedes et al. 2017) with little or no lignin (Joseleau et al. 2004; Pilate et al. 2004). The most recent proposed mechanisms of stress generation (Alméras \& Clair 2016) are based on the swelling of the mesoporous matrix of the G-layer during wood maturation (Chang et al. 2015) or the entrapment of rhamnogalacturonan I (RG-I) pectins (Gorshkova et al.2015) interacting with the cellulose microfibril network and inducing tension along the cellulose (Clair et al. 2011). When unlignified, the G-layer is easily detected in semi-thin anatomical sections because of its low lignin content compared with normal wood fibres allowing the use of cellulose-lignin double staining and because of its gel-like aspect and its detachment from the $S_{2}$ layer due to release of the internal stress during sectioning (Clair et al. 2005a, b). 
The G-layer does, however, show anatomical variation. G-layers may in some species be divided into sublayers by thin lignified layers apparently similar to an $\mathrm{S}_{3}$ layer (Ruelle et al. 2007). These G-layers are described as multilayered and may also contain various amounts of lignin (Ruelle et al.2007; Ghislain et al. 2016). In addition, several references indicate that the G-layer may contain various amounts of lignin, located in part of (Higaki et al. 2017) or in the whole G-layer (Ghislain \& Clair 2017). When the G-layer is fully lignified, it may be indistinguishable from a normal woody cell wall (Roussel \& Clair 2015). These species were considered to be without G-layers but in our recent review on the pattern of lignification in tension wood cell walls (Ghislain \& Clair 2017), the description of anatomical patterns was based on comments by other authors or on our interpretation of the illustrations present in their publications, which barely exceeded a few cells of tension wood. However, to enable a proper classification of lignified G-layers, careful observation of the fibre maturation process is needed (Roussel \& Clair 2015).

In some species, it seems that wood produced on the upper side of the stem lacks G-layers in all stages of development. It remains unclear if this wood produces high tensile stress as expected in tension wood, especially in the young stages, and we, therefore, prefer to name it reaction wood (Ghislain et al.2019, in press). This wood is characterised by thinner cell walls and enlarged parenchyma cells (Onaka 1949; Ghislain \& Clair 2017). The mechanism of tensile stress generation in these species relies on the interaction of both wood and bark (Clair et al. 2019). Phloem in these species is characterised by a trellis structure at the millimetre scale made of phloem fibres and filled with parenchyma cells. Eccentric radial wood growth leads to a tangential extension of the bark. This tangential extension is redirected in the longitudinal direction due to the trellis structure (see Figures 5 and 6 from Clair et al. 2019). This mechanism has proven to be as efficient as the G-layer mechanism to restore verticality in young saplings (Ghislain et al. 2019, in press). In adult trees, it remains unclear if wood may also contribute to the motor system in these species.

The first aim of this study is to describe the diversity of tension wood anatomy in a large number of species. As delayed lignification may occur (Roussel \& Clair 2015), we examined large sections of tension wood, including the cambial zone, allowing an unambiguous determination of the presence of the G-layer. Secondly, we aim to test an eventual correlation between the tension wood type or the lignification of G-layers and the ontogenetic stage or functional traits related to the ecology of the species. These relationships are expected to give a better understanding of the diversity in tension wood anatomy.

\section{MATERIALS AND METHODS}

Plant material was collected in French Guiana including both saplings and adult trees (Table 1). Most sampling was performed randomly, without any a priori choice of the species. 
Table 1. Description of plant material used for this study. The number of individuals, species and botanical families are indicated for juvenile trees, for adult trees, and for merged juvenile and adult trees.

\begin{tabular}{lccc}
\hline Plant material & Individuals & Species & Families \\
\hline Juvenile trees & 255 & 161 & 43 \\
Adult trees & 177 & 128 & 40 \\
Merged juvenile and adult trees & 432 & 242 & 51 \\
\hline
\end{tabular}

\section{Juvenile trees}

As most trees were sampled in the natural forest, the age of the tree was unknown, and we defined "juvenile trees" as trees with a diameter at the root collar below 2.7 $\mathrm{cm}$. Juvenile trees analysed in this study belong to several experimental setups:

1. Ninety-four naturally tilted juvenile trees covering 77 species belonging to 36 families were mainly sampled in September 2013 at the "Piste de Saint-Elie" IRD (Institut de Recherche pour le Développement) research station near Sinamary in French Guiana.

2. At the same site, 110 juveniles of 77 species belonging to 29 families were guyed at an angle of $45^{\circ}$ for 17 months to ensure tension wood production. Sampling locations were from three different environments with distinct conditions of waterlogging. Hilltop and slope had a low degree of waterlogging and bottomland had a high degree of waterlogging (Ferry et al.2010). The juvenile trees were sampled in April 2016.

3. Seeds and seedlings of 42 species within 23 families were collected in the tropical rainforest of French Guiana and grown in a greenhouse at the agronomic campus of the Research Unit EcoFoG in Kourou. After being transplanted in pots, they were staked and acclimatised in the experimentation greenhouse for one month. They were then tilted at $45^{\circ}$ for 2 to 11 months. Any stems sprouting at the base of the tilted stem were cut during the whole experiment to ensure tension wood production. For some species, up to 10 trees per species were grown. These replicates increased the robustness of the classification.

4. Additionally, anatomical sections from a previous study on juvenile trees grown in French Guiana and freely recovering from tilting were re-examined (Alméras et al. 2009). This added 8 species and 4 families to our study.

\section{Adult trees}

"Adult trees" were arbitrarily defined as trees for which the diameter at breast height (DBH) was higher than $4.5 \mathrm{~cm}$. DBH varied between $4.5 \mathrm{~cm}$ and $77.3 \mathrm{~cm}$. Naturally tilted adult trees with at least $11^{\circ}$ of lean were mainly sampled at the "Piste de SaintElie" in September and November 2014. These trees represent 142 individuals of 109 species and 39 families. In addition, 6 individuals of 4 species were sampled from naturally tilted trees near Paracou experimental station and 2 species were sampled from stem disks from previous studies, near the cambium on the upper side of leaning stems. 
Naturally tilted trees from previous studies made in French Guiana were added (Clair et al. 2006, 2019). In these studies, tension wood production was ensured by recording maturation stress. Tension wood maturation strain was at least 2 times and up to 24 times the values recorded in opposite wood. The study of Clair et al. (2006) added 21 species from 16 families and the study of Clair et al.(2019) added 6 species from 6 families.

In total, this study represents 432 individuals of 242 species, 149 genera, and 51 families. $63 \%$ of the species are represented by a single individual, $27 \%$ by 2 or 3 and $10 \%$ by 4 to 8 .

Compared to the tree species listed for French Guiana by Molino et al. (2009), our sampling covers $15 \%$ of species, $38 \%$ of genera and $65 \%$ of the families. At the Amazonian level, it represents $39 \%$ of the Amazonian families (51/131) and $83 \%$ $(33 / 40)$ of the 40 most common woody families (ter Steege et al. 2013).

\section{Microscopy}

Samples were kept wet (never air-dried) until sectioning; either in water when sectioning was expected within a few days following sampling, or in a water and ethanol mixture for longer storage. Bark was partially or totally removed on most samples. Sections of 20-50 $\mu \mathrm{m}$ thickness were cut with a sliding microtome and stained with safranin and astra blue 8GX. Safranin stains lignified cell walls red and astra blue stains unlignified cell walls blue. The sections were mounted on glass slides and observed using brightfield with an optical microscope (Olympus BX2).

To confirm the presence of lignin revealed by safranin and astra blue staining, we used a second technique on some duplicate samples. Sections of $2 \mu \mathrm{m}$ thickness were prepared with a diamond knife after embedding in LR White resin and observed without staining under the same microscope equipped with a mercury lamp (USH102D USHIO) generating light filtered with fluorescence filter cubes U-MNU2 (Olympus, excitation filter: 360-370 nm, dichromatic mirror: $400 \mathrm{~nm}$, emission filter: $420 \mathrm{~nm}$ ). Thanks to lignin autofluorescence, lignified cell walls are highlighted whereas unlignified cell walls remain dark (Roussel \& Clair 2015). Observation on duplicate samples with both techniques confirmed the accuracy of lignin detection revealed by safranin and astra blue staining with numerous patterns of lignification, even in a single section (Fig. 1).

For a few species (Gossypium hirsutum, Pachira aquatica, Theobroma cacao, and Theobroma grandiflorum), tangential or radial sections of normal wood and reaction wood of saplings staked and artificially tilted in a greenhouse were acquired to understand the anatomy of tension wood without G-layers.

\section{Anatomical groups}

Tension wood anatomy is highly diverse. Lignification of the G-layer is not a binary response but a gradient from unlignified to fully lignified with various patterns of lignification. In order to perform statistical analyses, a simplified classification of tension wood anatomy was needed. We, therefore, defined four anatomical groups based on the anatomy of reaction wood: three anatomical groups for tension wood with G-layers 
representing the variability of the degree of lignification of the G-layer, and one group for reaction wood without G-layers.
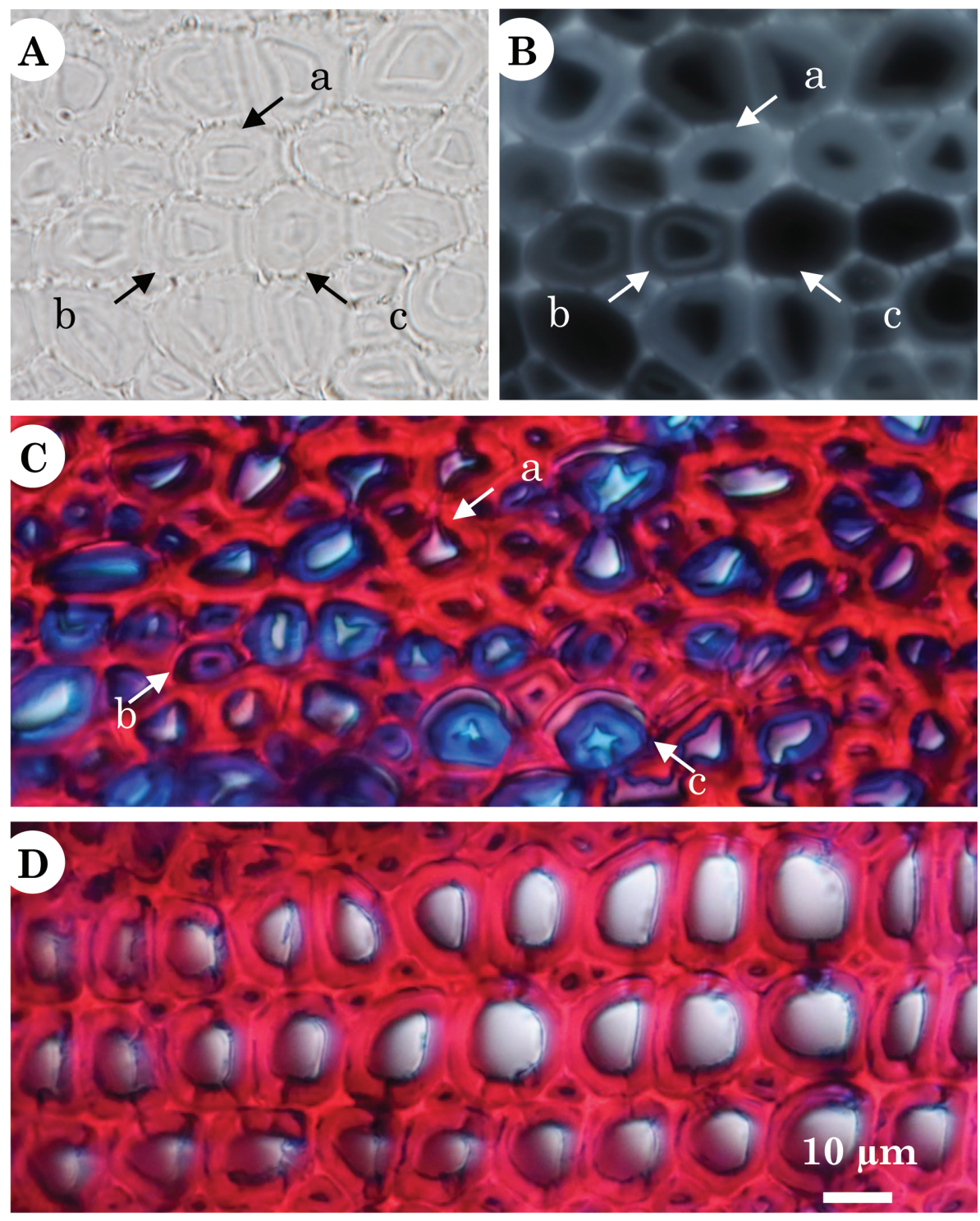

Figure 1. Comparison of tension wood (A, B, C) and normal wood (D) of Brosimum rubescens. A, B: unstained $2 \mu \mathrm{m}$ thin sections observed both with brightfield (A) and under UV light (B). C, D: $20-50 \mu \mathrm{m}$ sections stained with safranin and astra blue. Cambium is located on the left. Cell wall thickness (A) and lignin autofluorescence (B) allow detection of entirely lignified G-layers (a), partly lignified G-layers (b) and unlignified G-layers (c). As the stained section is thicker (C) it does not allow detection of lignin within the G-layer as precisely but gives information on the variability of the degree of lignification within G-layers. 

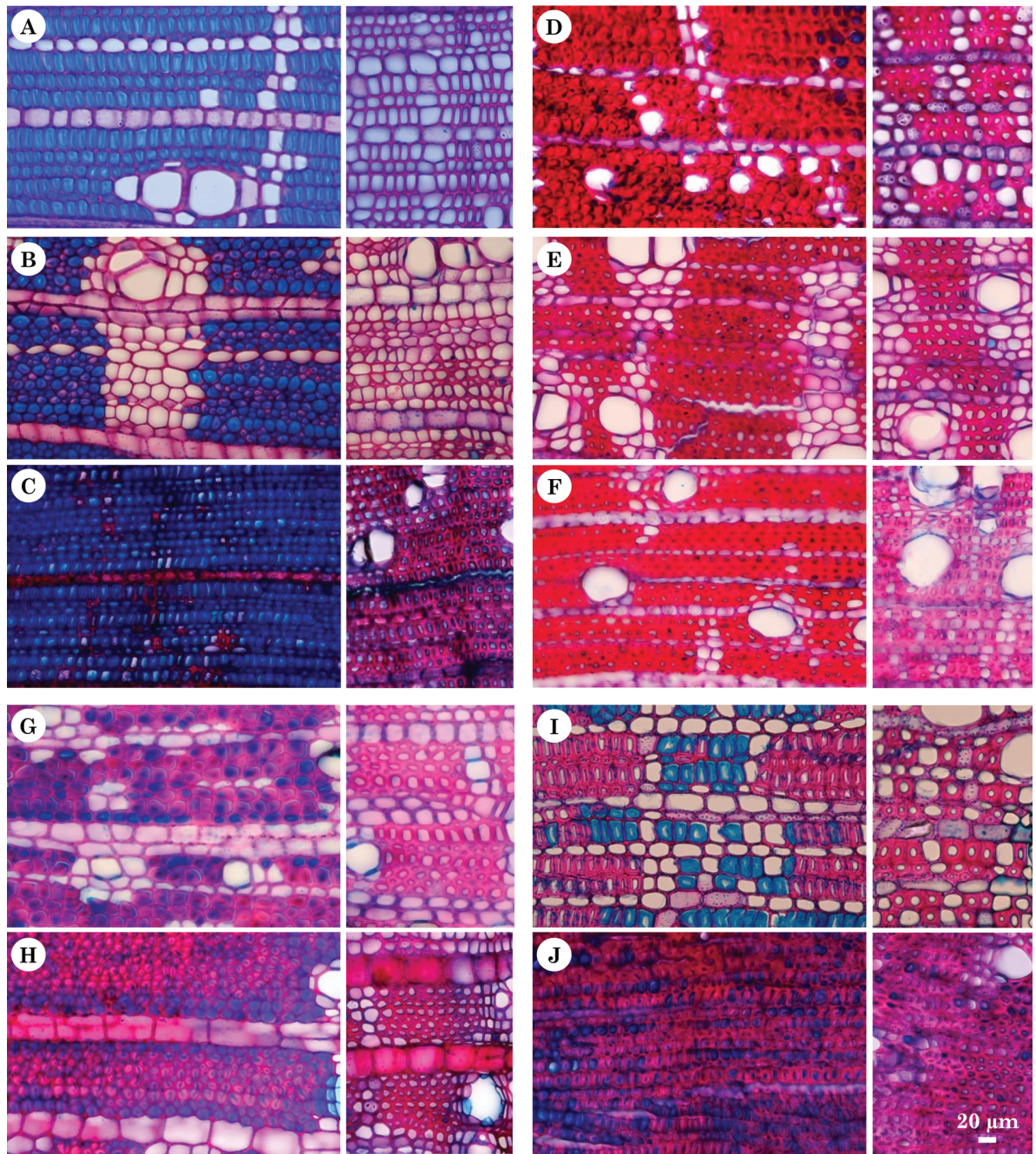

Figure 2. Patterns of lignification of the G-layers in tension wood. Tension wood (left) and opposite wood (right) of Hevea guianensis (A), Macrolobium bifolium (B), Protium guianense (C), Manilkara bidentata (D), Guarea guidonia (E), Licania macrophylla (F), Sextonia rubra (G), Eperua grandiflora $(\mathrm{H})$, Lacistema grandifolium (I), Tachigali melinonii (J). G-layers are either unlignified $(A-C)$, lignified $(D-F)$ or intermediate $(\mathrm{G}-\mathrm{J})$. Cambium is located on the right.

For tension wood with G-layers, we defined three anatomical groups based on the main trend in overall G-layer lignification of wood for which maturation is completed, including late lignification. If most of the mature G-layers are unlignified, the anatomical group is labeled "G-layer unlignified" (Fig. 2A-C). If mature G-layers have unlignified as well as lignified G-layers or have G-layers not completely lignified, the anatomical group is referred to as "G-layer partially lignified" (Fig. 2G-J). If all mature G-layers are lignified, the anatomical group is named "G-layer lignified" (Fig. 2D-F). 


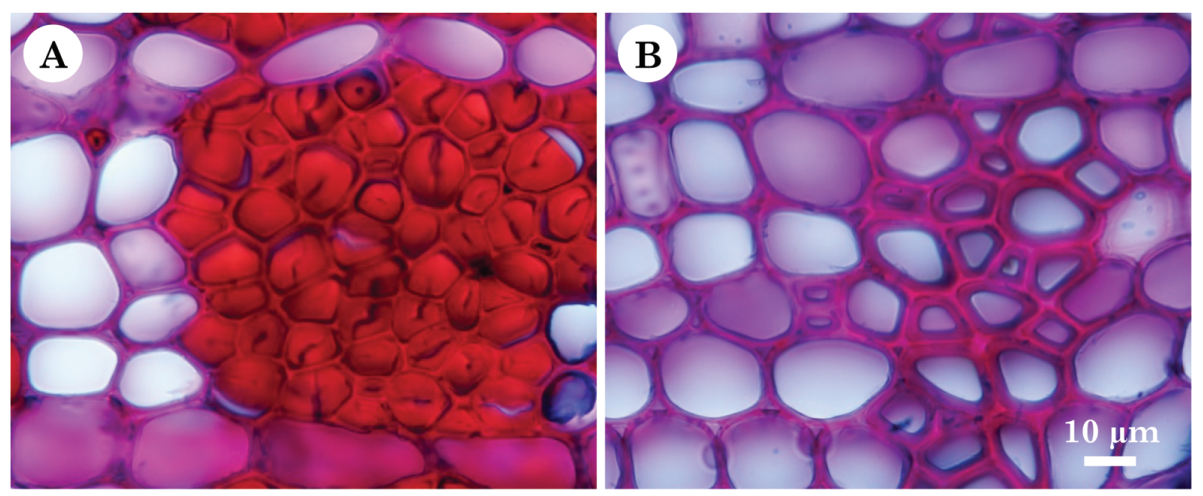

Figure 3. The difference in thickness of the fibre wall between tension wood (A) and normal wood fibres (B). Tension wood (A) and opposite wood (B) of Dicorynia guianensis. Note the detachment of the G-layer from the $\mathrm{S}_{2}$ layer and the difference in staining between the G-layer (A; deep red) and $\mathrm{S}_{2}$ layer of normal wood fibres (B; pink-red) within a single wood section of the whole stem.

The cell maturation phase could not always be observed, either because the tree was not growing at the sampling date (all cells adjacent to the cambium were mature) or in a few cases because the tension wood sector was located far from the cambium in some naturally tilted juvenile trees. When no unlignified G-layer was observed and when cell maturation could not be observed (60 individuals), lignified G-layers could be recognised either by the difference in thickness of the fibre wall compared with normal wood (Fang et al.2007; Abedini et al.2015), by the detachment from the $\mathrm{S}_{2}$ layer, or by a strong difference in the staining intensity compared with the normal fibre cell wall (Fig. 3).

After all individuals were assigned to an anatomical group, they were classified by species and by age to form 3 databases: juvenile trees (saplings), adult trees, and merged juvenile and adult trees (Table 1). Merging of the juvenile and adult data bases was mainly done to have a sufficient number of samples for testing statistical significance. For 32 species, different individuals belonged to divergent anatomical groups. These species were assigned to the most common anatomical group or to the anatomical group of the tree with the strongest reaction wood (artificially tilted $v s$ naturally leaning). In the merged juvenile and adult trees database, the anatomical group of the adult tree was used, when there was a difference between juvenile and adult reaction wood.

\section{Tests performed on the tension wood database}

Ontogenetic stage - In 46 species, both juvenile and adult trees were sampled. For these species, the anatomy of tension wood in both ontogenetic stages were compared to analyse whether changes occur during development.

Species light preferences - Species can be grouped as a function of their light regimes their habitat preferences related to light accessibility (Favrichon 1995), in the French literature sometimes referred to as "temperament". Tree species can be either light demanding, shade tolerant or shade demanding. Due to the large diversity of tree 
species in the tropical rainforest, the light preferences are not well documented for numerous species and are known for only a portion of our dataset. Light preferences were designated for 94 species into two classes: Light demanding or shade tolerant to shade demanding.

Wood density - Air-dry wood density (measured at $12 \%$ moisture content, D12) was reported for 107 of our species in Détienne \& Jacquet (1983) and for 49 species in Gérard et al. (2016). Overall, wood density has been reported for 114 of our species. In Détienne \& Jacquet (1983), wood density is categorised as lower than $0.65 \mathrm{~g} . \mathrm{cm}^{-3}$, between 0.65 and $0.85 \mathrm{~g} . \mathrm{cm}^{-3}$ and higher than $0.85 \mathrm{~g} . \mathrm{cm}^{-3}$. To compare lignification pattern in species with G-layers, this categorisation was simplified as below $0.85 \mathrm{~g} . \mathrm{cm}^{-3}$ and above $0.85 \mathrm{~g} . \mathrm{cm}^{-3}$. This threshold was chosen to ensure a good balance in the number of species within both groups.

\section{Statistical analysis}

Statistical analysis of categorised variables was performed using Chi-square tests at $95 \%$ confidence after verification of the conditions of applicability of the test. Tests were performed with Microsoft Excel. The null hypothesis stands for an absence of a significant correlation between the categorised variable and anatomical group.

\section{RESULTS}

\section{Anatomical group}

Tension wood with G-layers represents the majority of our sample ( $86 \%$ of the species; Table 2) compared to reaction wood without G-layers (14\%). "G-layer lignified" is the most common anatomical group of tension wood (57\%), "G-layer unlignified" is the rarest (9\%) and "G-layers partly lignified" represents $19 \%$ of the species.

Table 2. Classification of tension wood anatomy in the 3 databases: juvenile trees, adult trees, and merged juvenile and adult trees. N species: number of species; \% species: the proportion of species.

\begin{tabular}{lcccccc}
\hline & \multicolumn{2}{c}{ Juvenile trees } & \multicolumn{2}{c}{ Adult trees } & \multicolumn{2}{c}{$\begin{array}{c}\text { Merged juvenile } \\
\text { and adult trees }\end{array}$} \\
\hline $\begin{array}{l}\text { Tension/ } \\
\text { reaction wood anatomy }\end{array}$ & Nspecies & $\%$ species & Nspecies & $\%$ species & N species & $\%$ species \\
G-layer unlignified & 14 & 8.6 & 13 & 10.2 & 21 & 8.7 \\
G-layers partly lignified & 45 & 27.8 & 15 & 11.7 & 47 & 19.4 \\
G-layer lignified & 76 & 46.9 & 81 & 63.3 & 139 & 57.4 \\
Without G-layer & 26 & 16.7 & 19 & 14.8 & 35 & 14.5 \\
Total & $\mathbf{1 6 1}$ & $\mathbf{1 0 0}$ & $\mathbf{1 2 8}$ & $\mathbf{1 0 0}$ & $\mathbf{2 4 2}$ & $\mathbf{1 0 0}$ \\
\hline
\end{tabular}

\section{G-layers and lignification}

Unlignified G-layers appear in tension wood of most species, mostly near the cambium. However, species in which the G-layers remain unlignified far from the cambium, 
as in Populus (Pilate et al. 2004), are quite rare. Far from the cambium, unlignified G-layers are observed in only 9 species (Fig. 2A). For 12 species G-layers are mainly unlignified but slight staining for lignin is sometimes observed inside fibres, either towards the edges of the cell (Fig. 2B) or in the whole G-layer.

At the cell level, the G-layer has either a homogeneous or heterogeneous staining of the whole G-layer, which can be more or less intense (Fig. 1). At the tissue level, in $57 \%$ of the species all G-layers were fully and homogeneously lignified far away from the cambium (Fig. 2D-F). In $19 \%$ of the species, lignification could occur in some G-layers and not in others, with heterogeneous staining or not and in a random pattern or not (Fig. 2G-J). For example, in Pourouma sp.1, lignified G-layers occurred on the borders of the tension wood arc only.

In 134 individuals of the anatomical group "G-layer lignified", the maturation lasted long enough to observe the lignification process. Lignification occurs either after the G-layer had reached its final thickness (30\% of 134 individuals; like Simarouba amara, studied in detail by Roussel \& Clair (2015)) or during cell wall thickening (70\% of 134 individuals; Fig. 4B), often with a delay between wall thickening and lignification.

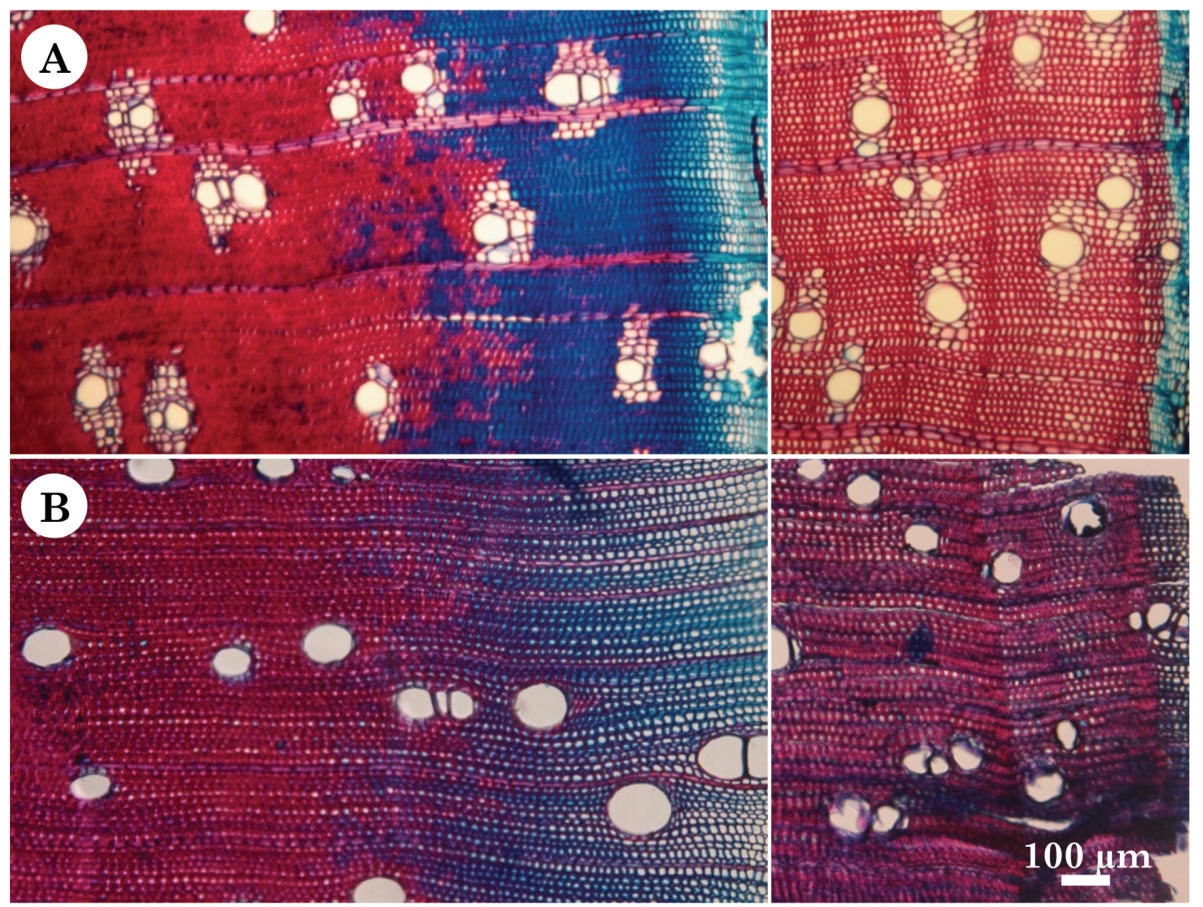

Figure 4. Lignification occurrence during cell maturation in the G-layers: either after G-layer thickening was completed (A) or during G-layer thickening (B). Tension wood (left) and opposite wood (right) of Ocotea percurrens (A) and Cupania scrobiculata (B). Cambium is located on the right. 

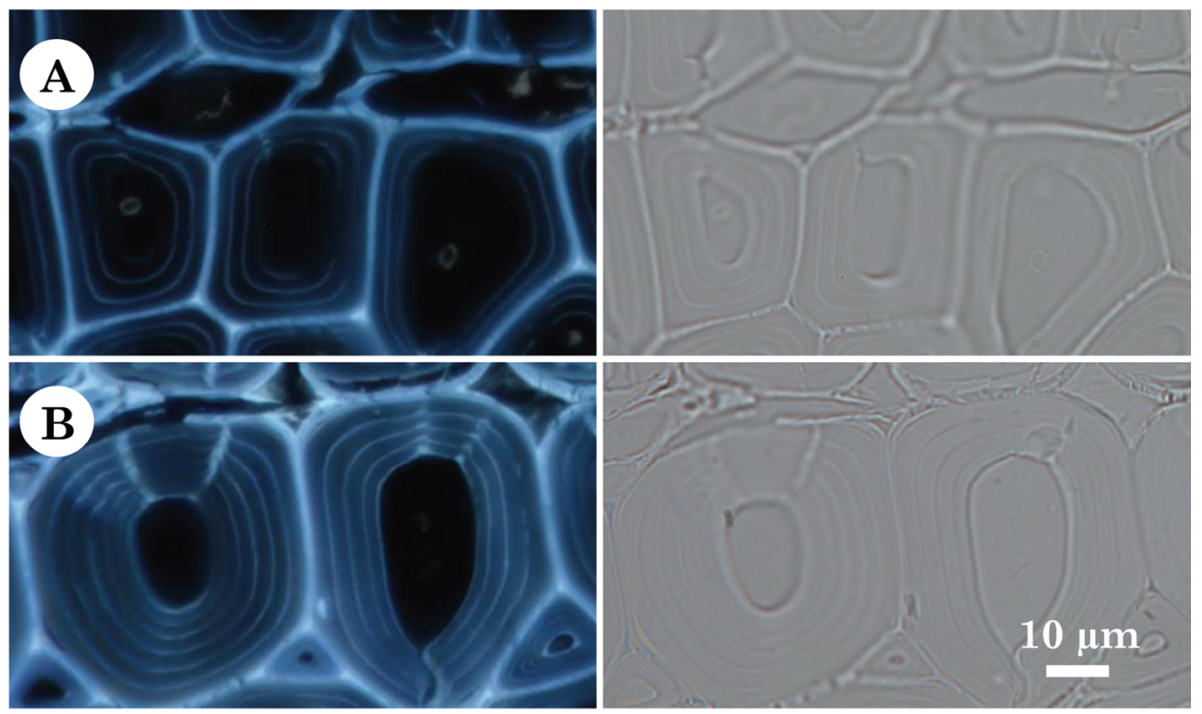

Figure 5. Multilayered G-layer of Laetia procera in $2 \mu \mathrm{m}$ thin unstained sections observed both with UV light (left) and brightfield (right). Multilayered G-layers during cell wall maturation (A) and after completion of cell wall thickening (B). Note the thin lignified layers dividing the G-layer.

\section{Multilayered G-layers}

Independently from G-layer lignification, G-layers may be multilayered, at least divided into two sublayers by thin lignified layers (Fig. 5) described as an $\mathrm{S}_{3}$ layer by Ruelle et al. (2007). Multilayered G-layers were not frequently observed. A few isolated multilayered G-layers occurred sometimes in tension wood of diverse species. Most of, or all G-layers of tension wood are multilayered in 9 species (Licaria martiniana (Lauraceae), Banara guianensis, Casearia javitensis and Laetia procera (Salicaceae)) and in 5 of the 7 species of Euphorbiaceae examined (Conceveiba guianensis, Hevea guianensis, Mabea sp., Sandwithia guianensis, and one of the two individuals of Sagotia racemosa). G-layers were divided into two sublayers in Hevea guianensis, Licaria martiniana, and Mabea sp. whereas they could be divided into a higher number of sublayers in the rest of these species.

In two-thirds of the individuals of Burseraceae and in Tapirira obtusa and Thyrsodium puberulum, the G-layer seems divided into two sublayers. Thin unstained sections of tension wood of Protium decandrum (Burseraceae) observed for lignin autofluorescence confirmed that these G-layers are not divided by thin lignified layers as in Figure 5, but rather have a difference in lignin between the outer and inner part of the G-layer which is around 50\% thickness of the G-layer. It is not clear, however, if the inner and outer parts are both G-layers or if the external one is an $S_{2}$ layer, which is then less stained than in normal wood.

In individuals in which the G-layer of the fibre cell wall is very thick and completely lignified, concentric bulges were sometimes observed. However, these are not considered as multilayered G-layers, as no clear layering was observed. 


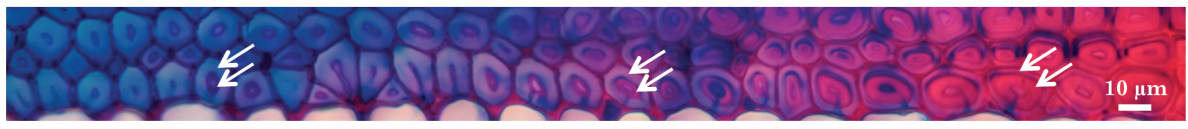

Figure 6. Progressive bi-layering of the G-layer in Dendrobangia boliviana. Cambium is located further to the right (not visible). Progressive bi-layering occurs with a change of lignification in this species. Arrows indicate the two layers in three different G-layers.

In 8 species (Dendrobangia boliviana, Garcinia benthamiana, Inga gracilifolia, Platonia insignis, Symphonia globulifera, Symphonia sp.1, Tovomita sp. 1 and maybe Tapura guianensis), G-layers were divided into two sublayers in a radial file of around 30 fibres, with the inner layer becoming thinner as the outer one is thickening when moving away from the cambium. The other G-layers of these individuals are not multilayered. This progressive bi-layering is sometimes associated with transition zones (Inga gracilifolia and possibly Tovomita sp.1) between normal wood and tension wood but sometimes occurs in the middle of a tension wood sector as was observed in 4 juvenile trees of Dendrobangia boliviana. In this species, progressive bi-layering occurs with a change in lignification of the G-layer (Fig. 6). The reason for a sudden change in lignification of the G-layer of this species is unknown, as the three individuals were juvenile and came from both naturally and artificially tilted trees. The three adult trees of this species had lignified G-layers, without any progressive bi-layering. G-layers in progressive bi-layering are not considered as multilayered G-layers.

\section{Reaction wood without G-layers}

Reaction wood without G-layers is recognised by its reduced fibre wall thickness compared to normal wood. It is not always clear in our transverse sections whether the thin-walled cells of reaction wood are axial parenchyma or fibres, therefore tangential or radial sections were examined in Gossypium hirsutum, Pachira aquatica, Theobroma cacao and Theobroma grandiflorum (Fig. 7). In these species at least, parenchyma cell size and proportion of fibres and parenchyma are modified in the reaction wood. These modifications of the anatomy in reaction wood compared to normal wood are emphasised in juvenile trees. In adult trees, reaction wood anatomy looks sometimes similar to that of normal wood, except for the eccentricity in growth recorded on the upper side.

Reaction wood without G-layers was identified in 34 species (14\% of the species). One of the species is of undetermined botanical affinity. The other 33 species belonged to 8 botanical families: Annonaceae (10 species), Bignoniaceae (1 species), Boraginaceae (3 species), Lamiaceae (1 species), Malvaceae (11 species), Myristicaceae (4 species), Styracaceae (1 species) and Verbenaceae (1 species). All species examined from these families except Annonaceae had reaction wood without G-layers. In Annonaceae, among the 14 species examined, 10 were classified as without a G-layer and, surprisingly, a lignified G-layer was highly suspected in 4 species: Guatteria guianensis, Guatteria schomburgkiana, Oxandra asbeckii, and Xylopia crinita. Although cell maturation could not be observed, differences in cell wall staining as in Figure 3 were observed. Tension wood in these species came from naturally 

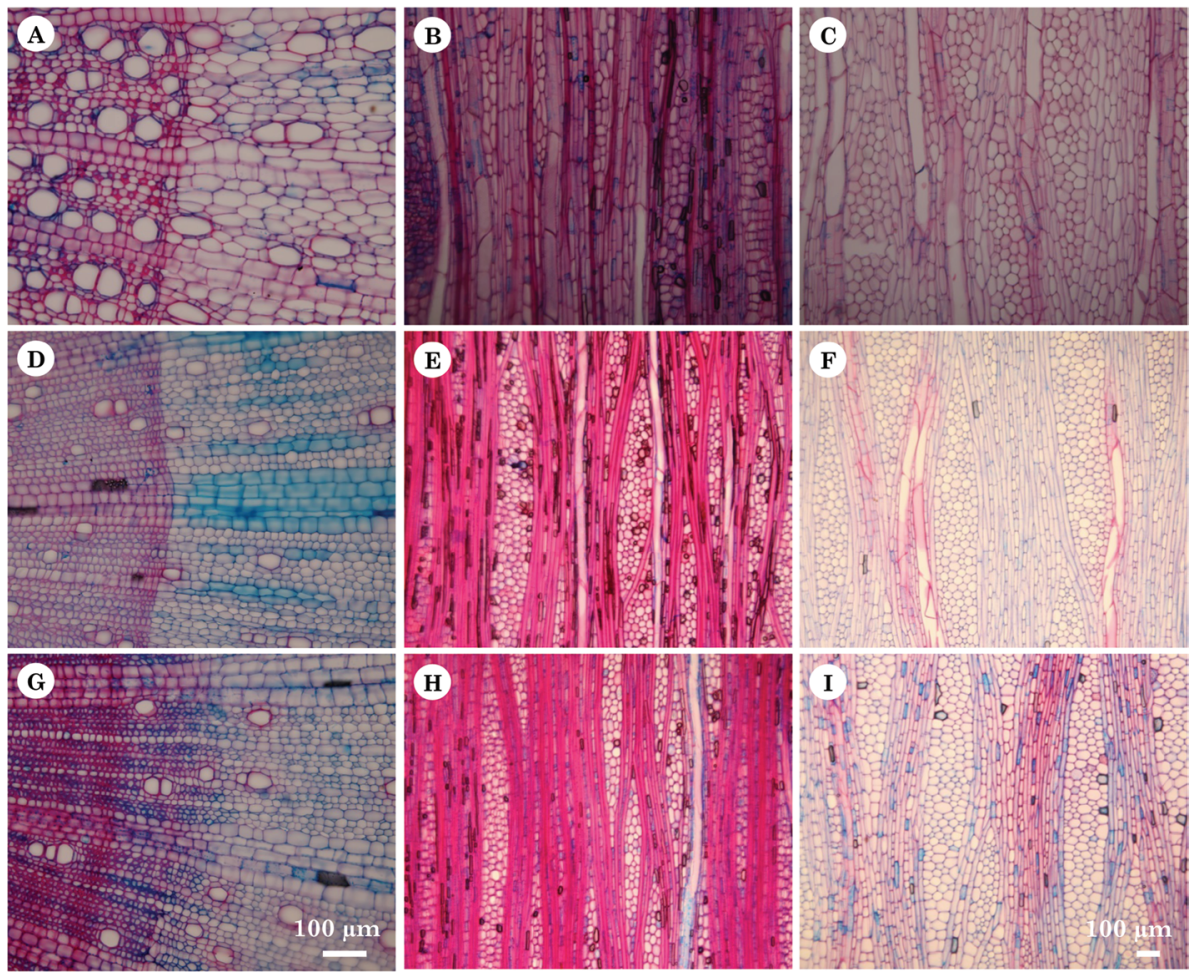

Figure 7. Transverse section of transition between normal wood and reaction wood (A, D, G) and tangential section of opposite wood $(\mathrm{B}, \mathrm{E}, \mathrm{H})$ and reaction wood $(\mathrm{C}, \mathrm{F}, \mathrm{I})$ of artificially staked tilted saplings of Pachira aquatica (A-C), Theobroma cacao (D-F) and Theobroma grandiflorum $(\mathrm{G}-\mathrm{I})$. Note fibres are almost absent in reaction wood compared to normal or opposite wood (Photos H. Morel).

leaning trees in the forest. Artificially tilted trees would be needed to complete our observation of tension wood anatomy in these species.

\section{Change in anatomical group during ontogeny}

Forty-six among the 242 species were sampled both as juvenile and adult, but in half of them, either juvenile or adult was not clearly assigned to a group because different individuals presented different lignification patterns (for example lignified and partly lignified G-layers). As a result, only 23 species remain for comparison.

Among the 10 species from the anatomical group "without G-layer" in the juvenile stage, none of them switch to the group "with G-layer" in the adult stage but one adult tree of Iryanthera hostmannii and one of Iryanthera sagotiana were suspected to have lignified G-layers. Differences between normal wood and reaction wood are less marked in adult trees of the species "without G-layer", except for the eccentric growth.

In 36 species sampled in both adult and juvenile trees with a G-layer in the tension wood, we found no consistent pattern in the change of anatomical group during ontogeny. 


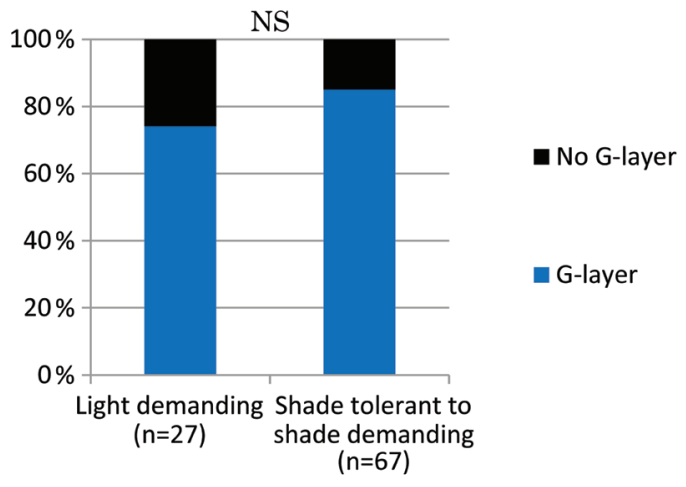

Figure 8. Anatomical groups with or without G-layers and light demands of species in the merged adult and juvenile dataset. The difference between both groups is not significant (NS: $\mathrm{p}>0.05)$.

\section{Light preferences}

Light preferences were determined for 94 species from the merged dataset. Anatomical groups with or without G-layers do not significantly depend on the light preferences of the species ( $p>0.05$; Fig. 8). Species without G-layers are found in light demanding species such as Cordia alliodora as well as in shade tolerant or shade demanding species like Anaxagorea dolichocarpa.

The anatomical group with G-layers is significantly dependent on light preferences in the merged juvenile and adult dataset ( $<<0.001$; Fig. 9). Unlignified G-layers are significantly more represented in light demanding species. Among the 57 shade tolerant to shade demanding species, only Brosimum parinarioides and Eperua falcata were reported to have unlignified G-layers. When data are split between juvenile trees and adult trees, the number of individuals in each group is too low and in both ontogenetic stages the difference is not statistically significant ( $p>0.05$; Fig. 9), but the trend remains the same.
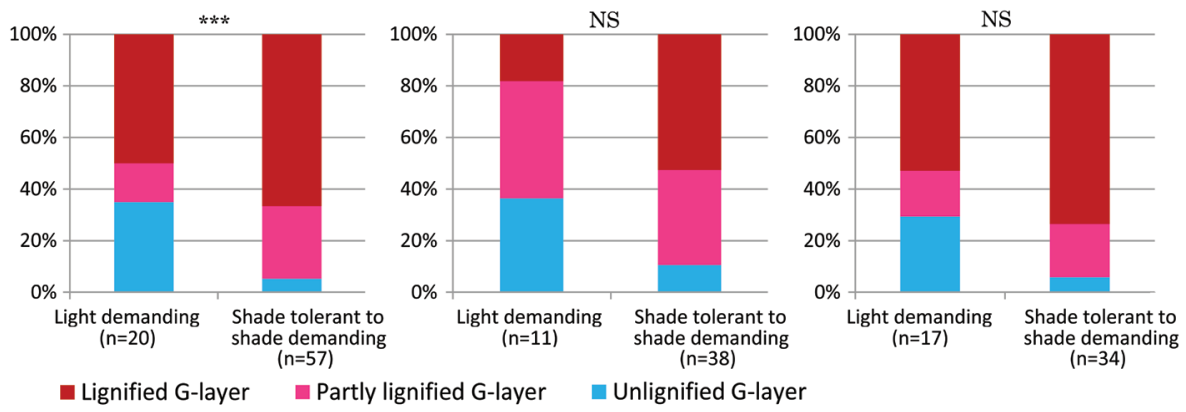

Figure 9. Anatomical groups with G-layers and light demands of species in the merged adult and juvenile dataset (left), the juvenile trees only dataset (middle) and the adult trees only dataset (right). Significance level indicated (NS: $\mathrm{p}>0.05 ; * * * \mathrm{p}<0.001$ ). 


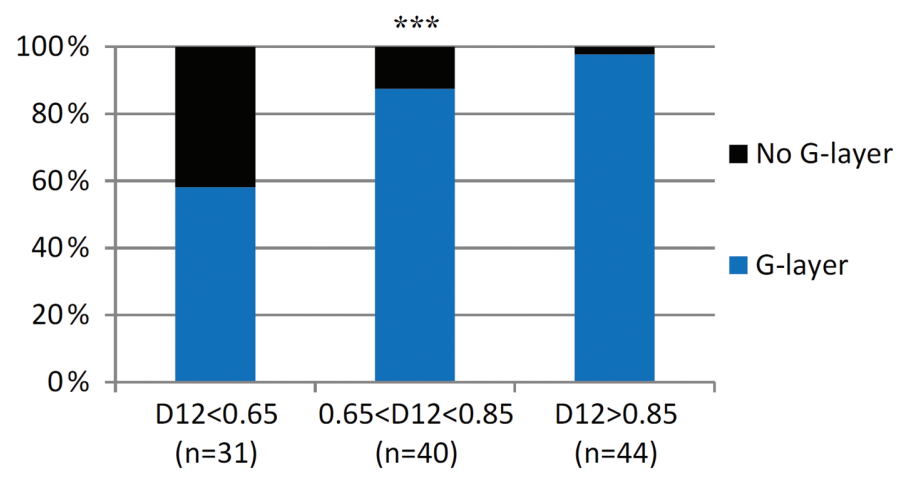

Figure 10. Anatomical groups with or without G-layers and wood density at $12 \%$ relative humidity (D12) in the merged adult and juvenile dataset. Significance level indicated $(* * *: p<0.001)$.

\section{Wood density}

Presence or absence of a G-layer in tension/reaction wood is significantly linked to wood density ( $p<0.001$; Fig. 10). Species with a low wood density most often have reaction wood without a G-layer. Of the 19 species of the anatomical group "No Glayer" for which wood density information was available, only Duguetia surinamensis had a density higher than $0.85 \mathrm{~g} . \mathrm{cm}^{-3}$.

Among the anatomical groups with G-layers, one has a significant relationship with wood density $(\mathrm{p}<0.001$; Fig. 11). G-layers are more likely to be lignified in species for which wood density is higher than $0.85 \mathrm{~g} . \mathrm{cm}^{-3}$. Among the 44 species for which wood density is higher than $0.85 \mathrm{~g} . \mathrm{cm}^{-3}$, only Brosimum parinarioides and Eperua falcata belong to the anatomical group "G-layer unlignified" and only Brosimum rubescens, Eperua grandiflora, Hymenae courbaril, and Poecilanthe hostmanii belong to the anatomical group "G-layer partly lignified". Similar results are obtained in juvenile trees $(\mathrm{p}<0.001$; Fig. 11) but in adult trees alone the difference is not significant ( $p>0.05$; Fig. 11).
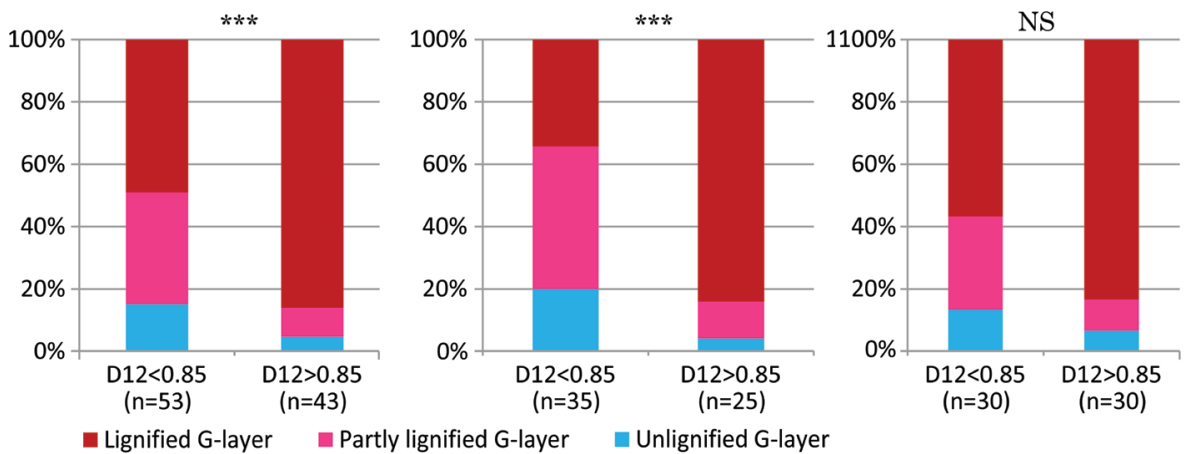

Figure 11. Anatomical groups with G-layers and wood density at $12 \%$ relative humidity (D12) in the merged adult and juvenile dataset (left), the juvenile trees only dataset (middle) and the adult trees only dataset (right). Significance level indicated (NS: $p>0.05 ; * * *: p<0.001$ ). 


\section{DISCUSSION}

\section{Tension/reaction wood is anatomically diverse}

A key result of this study is the high diversity among species and variability within species of the anatomy of tension wood and the discovery of an alternative type of reaction wood in tropical angiosperm trees. As in most studies regarding diversity, the classification into groups is useful for a better understanding but is not unambiguous. From the anatomical point of view, classifying tension wood into groups is challenging, especially on the criterion of lignification of the G-layer, which can vary in one given species and even within one individual or within one cell wall layer. Despite the agreement with other methods recorded in the preliminary tests and all the attention paid to the quality and reproducibility of the staining, it cannot be excluded that slight variations in the staining protocol may have influenced the results. Additional variations of the G-layer were observed, such as multilayered G-layers, layering in the lignin content (Protium decandrum) and progressive bi-layering (Dendrobangia boliviana).

In the anatomical group "without G-layers”, evidence of enlarged parenchyma cells in reaction wood is presented for 4 species. However, in species with denser wood such as Duguetia surinamensis reaction wood seems to have fibres with decreased cell wall thickness. Reaction wood anatomy is less contrasted in adult trees than in juvenile trees. Species without a G-layer may share a common mechanism of uprighting based on the interaction between wood and bark (Clair et al.2019). This mechanism is mainly found in species with low wood density which makes sense as a motor based in bark is even more efficient when wood is less stiff and wood growth rate is high. When found in species of high wood density generally associated with low growth rate, one can wonder how bark could bend a stem that has high wood density and a low radial growth rate.

Species without a G-layer in their reaction wood accounted for only $14 \%$ of the tree species examined and are only present in a few botanical families mostly characterised by wide rays, and bark with stratified fibres such as the Malvaceae sensu lato (Angyalossy et al. 2016).

\section{In the tropical forest, most species have lignified G-layers}

Most tropical tree species produce tension wood with a G-layer to generate tensile stress ( $86 \%$ of the species; Table 2). This result contrasts with previous studies on tropical tree species indicating that only one-third of the species have G-layers in their tension wood (Onaka 1949; Fisher \& Stevenson 1981; Clair et al. 2006). In these former studies, lignified G-layers were assigned as reaction wood without G-layers. However, according to our observations, G-layers in mature wood are mainly lignified (57\% of the species). As unlignified G-layers are able to bend the tree upward, we wonder why the tree invests in additional lignification of this layer. Several hypotheses can be proposed. Lignification of the G-layer may improve the stress generation, the efficiency of tension wood to bend the tree upward. However, experiments on the gravitropic movements of 21 species showed that lignified G-layers produced similar maturation strains of tension wood as unlignified G-layers (Ghislain et al. 2019, in press). 
Lignification may also fix or stabilise the stress and maintain its efficiency over time. Finally, lignification of the G-layer may also improve the defence system of the tree against pathogen attack. Unlignified G-layers can be easily degraded by fungi (Encinas \& Daniel 1997) whereas the presence of lignin or polyphenols helps the G-layer to resist wood-decaying fungi (Schmitt et al. 1995; Daniel \& Nilsson 1996; Schwarze \& Fink 1998; Baum et al.2000; Singh et al. 2004). Our data support this last hypothesis as lignified G-layers were found more often in long-living shade-tolerant species with high wood density.

\section{ACKNOWLEDGEMENTS}

We thank Jocelyn Cazal, Audin Patient and Jean-Yves Goret for their help in the greenhouse, Eric Nicolini for light preferences assignation, Pascal Petronelli for additional botanical determination, Jacques Beauchêne for wood determination, Hélène Morel for help on tangential sectioning, all the students following the AgroParisTech's FTH training courses (2013, 2014), Agnès Burgers, Gauthier Crépy, Emma Lord, Clémence Ogéron, Aurélie Cuvelier, Hélène Fargeon, Cécilia Gauvin, and Nicolas Gentis who helped with sampling and sectioning and Pieter Baas for the critical reading of our manuscript. This work was supported by the French National Research Agency in the framework of the project "StressInTrees" [ANR-12-BS09-0004] and by an "Investissements d'Avenir" grant from the Center for the Study of Biodiversity in Amazonia, managed by the French National Research Agency [CEBA, ANR-10-LABX-25-01 to B.G.].

\section{REFERENCES}

Abedini R, Clair B, Pourtahmasi K, Laurans F, Arnould O. 2015. Cell wall thickening in developing tension wood of artificially bent poplar trees. IAWA J. 36: 44-57. DOI: 10.1163/2294 1932-00000084.

Alméras T, Clair B. 2016. Critical review on the mechanisms of maturation stress generation in trees. J. R. Soc. Interface 13: 20160550. DOI: 10.1098/rsif.2016.0550.

Alméras T, Derycke M, Jaouen G, Beauchêne J, Fournier M. 2009. Functional diversity in gravitropic reaction among tropical seedlings in relation to ecological and developmental traits. J. Exp. Bot. 60: 4397-4410. DOI: 10.1093/jxb/erp276.

Alméras T, Fournier M. 2009. Biomechanical design and long-term stability of trees: Morphological and wood traits involved in the balance between weight increase and the gravitropic reaction. J. Theor. Biol. 256: 370-381. DOI: 10.1016/j.jtbi.2008.10.011.

Angyalossy V, Pace MR, Evert RF, Marcati CR, Oskolski AA, Terrazas T, Kotina E, Lens F, Mazzoni-Viveiros SC, Angeles G, Machado SR, Crivellaro A, Rao KS, Junikka L, Nikolaeva N, Baas P. 2016. IAWA list of microscopic bark features. IAWA J. 37: 517-615. DOI: 10.1163/22941932-20160151.

Baum S, Schwarze FWMR, Fink S. 2000. Persistence of the gelatinous layer within altered tension-wood fibres of beech degraded by Ustulina deusta. New Phytol. 147: 347-355. DOI : 10.1046/j.1469-8137.2000.00706.x.

Chang S-S, Quignard F, Alméras T, Clair B. 2015. Mesoporosity changes from cambium to mature tension wood: a new step toward the understanding of maturation stress generation in trees. New Phytol. 205: 1277-1287. DOI: 10.1111/nph.13126.

Chave J, Coomes D, Jansen S, Lewis SL, Swenson NG, Zanne AE. 2009. Towards a worldwide wood economics spectrum. Ecol. Lett. 12: 351-366. DOI: 10.1111/j.1461-0248.2009.01285.x.

Clair B, Alméras T, Pilate G, Jullien D, Sugiyama J, Riekel C. 2011. Maturation stress generation in poplar tension wood studied by synchrotron radiation microdiffraction. Plant Physiol. 155: 562-570. DOI: 10.1104/pp.110.167270. 
Clair B, Ghislain B, Prunier J, Lehnebach R, Beauchêne J, Alméras T. 2019. Mechanical contribution of secondary phloem to postural control in trees: the bark side of the force. New Phytol. 221: 209-217. DOI: 10.1111/nph.15375.

Clair B, Gril J, Baba K, Thibaut B, Sugiyama J. 2005a. Precautions for the structural analysis of the gelatinous layer in tension wood. IAWA J. 26: 189-195. DOI: 10.1163/2294193290000110 .

Clair B, Gril J, Di Renzo F, Yamamoto H, Quignard F. 2008. Characterization of a gel in the cell wall to elucidate the paradoxical shrinkage of tension wood. Biomacromolecules 9: 494-498. DOI: 10.1021/bm700987q.

Clair B, Ruelle J, Beauchêne J, Prévost M-F, Fournier M. 2006. Tension wood and opposite wood in 21 tropical rain forest species. 1. Occurrence and efficiency of G-layer. IAWA J. 27: 329-338. DOI: 10.1163/22941932-90000158.

Clair B, Thibaut B, Sugiyama J. 2005b. On the detachment of the gelatinous layer in tension wood fiber. J. Wood. Sci. 51: 218-221. DOI: 10.1007/s10086-004-0648-9.

Daniel G, Nilsson T. 1996. Polylaminate concentric cell wall layering in fibres of Homalium foetidum and its effect on degradation by microfungi. In: Donaldson LA, Butterfield BG, Whitehouse L (eds.), Recent Advances in Wood Anatomy: 369-372. New Zealand Forest Research Institute, Rotorua.

Détienne P, Jacquet P. 1983. Atlas d'identification des bois de l'amazonie et des régions voisines. GERDAT - CTFT, Nogent-sur-Marne.

Dlouhá J, Alméras T, Beauchêne J, Clair B, Fournier M. 2018. Biophysical dependences among functional wood traits. Funct. Ecol. 32: 2652-2665. DOI: 10.1111/1365-2435.13209.

Encinas O, Daniel G. 1997. Degradation of the gelatinous layer in aspen and rubberwood by the blue stain fungus Lasiodiplodia theobromae. IAWA J. 18: 107-115. DOI: 10.1163/2294 1932-90001471.

Fang C-H, Clair B, Gril J, Alméras T. 2007. Transverse shrinkage in G-fibers as a function of cell wall layering and growth strain. Wood Sci. Technol. 41: 659-671. DOI: 10.1007/ s00226-007-0148-3.

Favrichon V. 1995. Modèle matriciel déterministe en temps discret: Application à l'étude de la dynamique d'un peuplement forestier tropical humide (Guyane Française). Thesis, Université Lyon 1, Lyon, $252 \mathrm{pp}$.

Ferry B, Morneau F, Bontemps J-D, Blanc L, Freycon V. 2010. Higher treefall rates on slopes and waterlogged soils result in lower stand biomass and productivity in a tropical rain forest: Treefall and biomass in a tropical rain forest. J. Ecol. 98: 106-116. DOI: 10.1111/j.13652745.2009.01604.x.

Fisher JB, Stevenson JW. 1981. Occurrence of reaction wood in branches of dicotyledons and its role in tree architecture. Bot. Gaz. 142: 82-95. DOI: 10.1086/337199.

Fortunel C, Ruelle J, Beauchêne J, Fine PVA, Baraloto C. 2014. Wood specific gravity and anatomy of branches and roots in 113 Amazonian rainforest tree species across environmental gradients. New Phytol. 202: 79-94. DOI: 10.1086/337199.

Fournier M, Dlouhá J, Jaouen G, Alméras T. 2013. Integrative biomechanics for tree ecology: beyond wood density and strength. J. Exp. Bot. 64: 4793-4815. DOI: 10.1093/jxb/ert279.

Gardiner BA, Barnett J, Saranpää P, Gril J. 2014. The biology of reaction wood. Springer, Heidelberg, New York.

Gérard J, Guibal D, Paradis S, Cerre J-C. 2016. Atlas des bois tropicaux: caractéristiques technologiques et utilisations.

Ghislain B, Alméras T, Prunier J, Clair B. 2019. Contributions of bark and tension wood and role of the G-layer lignification in the gravitropic movements of 21 tropical tree species. Ann. For. Sci. (in press). 
Ghislain B, Clair B. 2017. Diversity in the organisation and lignification of tension wood fibre walls - A review. IAWA J. 38: 245-265. DOI: 10.1163/22941932-20170170.

Ghislain B, Nicolini E-A, Romain R, Ruelle J, Yoshinaga A, Alford MH, Clair B. 2016. Multilayered structure of tension wood cell walls in Salicaceae sensu lato and its taxonomic significance. Bot. J. Linn. Soc. 182: 744-756. DOI: 10.1111/boj.12471.

Gorshkova T, Mokshina N, Chernova T, Ibragimova N, Salnikov V, Mikshina P, Tryfona T, Banasiak A, Immerzeel P, Dupree P, Mellerowicz EJ. 2015. Aspen tension wood fibers contain $\beta$ - $(1 \rightarrow 4)$-galactans and acidic arabinogalactans retained by cellulose microfibrils in gelatinous walls. Plant Physiol. 169: 2048-2063. DOI: 10.1104/pp.15.00690.

Guedes FTP, Laurans F, Quemener B, Assor C, Lainé-Prade V, Boizot N, Vigouroux J, LesageDescauses M-C, Leplé J-C, Déjardin A, Pilate G. 2017. Non-cellulosic polysaccharide distribution during G-layer formation in poplar tension wood fibers: abundance of rhamnogalacturonan I and arabinogalactan proteins but no evidence of xyloglucan. Planta 246: 857-878. DOI: $10.1007 / \mathrm{s} 00425-017-2737-1$.

Higaki A, Yoshinaga A, Takabe K. 2017. Heterogeneous distribution of xylan and lignin in tension wood G-layers of the S1+G type in several Japanese hardwoods. Tree Physiol. 37: 1767-1775. DOI: 10.1093/treephys/tpx144.

IAWA Committee. 1964. Multilingual glossary of terms used in wood. Verlagsbuchanstalt Konkordia, Winterthur.

Joseleau J-P, Imai T, Kuroda K, Ruel K. 2004. Detection in situ and characterization of lignin in the G-layer of tension wood fibres of Populus deltoides. Planta 219: 338-345. DOI: 10.1007/s00425-004-1226-5.

Lehnebach R, Doumerc L, Clair B, Alméras T. 2019. Mechanical stress in inner bark of 15 tropical tree species and relation with anatomical structure. Botany. DOI: 10.1139/cjb-2018-0224.

Molino J-F, Sabatier D, Prévost M-F, Frame D, Gonzales S, Bilot-Guérin V. 2009. Convention E 24/08 entre le Ministère de l'Agriculture et de la Pêche et l'IRD, dans le cadre du Programme 149 Forêt BOP 14901C, sous-action 15, destiné a la réalisation du programme intitulé «Établissement d'une liste des espèces d'arbres de la Guyane Française» - Rapport final.

Morris H, Jansen S. 2016. Secondary xylem parenchyma - From classical terminology to functional traits. IAWA J. 37: 1-15. DOI: 10.1163/22941932-20160117.

Moulia B, Coutand C, Lenne C. 2006. Posture control and skeletal mechanical acclimation in terrestrial plants: implications for mechanical modeling of plant architecture. Am. J. Bot. 93: 1477-1489. DOI: 10.3732/ajb.93.10.1477.

Onaka F. 1949. Studies on compression and tension wood. Wood Res. 1-88.

Pilate G, Chabbert B, Cathala B, Yoshinaga A, Leplé J-C, Laurans F, Lapierre C, Ruel K. 2004. Lignification and tension wood. C.R. Biol. 327: 889-901. DOI: 10.1016/j.crvi.2004. 07.006 .

Rosell JA. 2016. Bark thickness across the angiosperms: more than just fire. New Phytol. 211: 90-102. DOI: $10.1111 /$ nph.13889.

Rosell JA, Olson ME. 2014. The evolution of bark mechanics and storage across habitats in a clade of tropical trees. Am. J. Bot. 101: 764-777. DOI: 10.3732/ajb.1400109.

Roussel J-R, Clair B. 2015. Evidence of the late lignification of the G-layer in Simarouba tension wood, to assist understanding how non-G-layer species produce tensile stress. Tree Physiol. 35: 1366-1377. DOI: 10.1093/treephys/tpv082.

Ruelle J, Yoshida M, Clair B, Thibaut B. 2007. Peculiar tension wood structure in Laetia procera (Poepp.) Eichl. (Flacourtiaceae). Trees 21: 345-355. DOI: 10.1007/s00468-007-0128-0.

Schmitt U, Peek R-D, Wong A. 1995. A note on the fine structure of soft rot decay in the polylamellate fibre walls of kempas (Koompassia malaccensis Maing. ex Benth.). Holz Roh- Werkst. 54: 42-42. DOI: 10.1007/s001070050129. 
Schwarze FWMR, Fink S. 1998. Host and cell type affect the mode of degradation by Meripilus giganteus. New Phytol. 139: 721-731. DOI: 10.1046/j.1469-8137.1998.00238.x.

Singh AP, Wong AHH, Kim YS, Wi SG. 2004. The relationship of fiber cell wall ultrastructure to soft rot decay in kempas (Koompassia malaccensis) heartwood. IRG 35. Ljubljana, Slovenia.

ter Steege H, et al. 2013. Hyperdominance in the Amazonian tree flora. Science 342: 1243092 1243092. DOI: $10.1126 /$ science.1243092. 